CLINICAL STUDY

\title{
D3 GH receptor polymorphism is not associated with IGF1 levels in untreated acromegaly
}

\author{
Peter Kamenicky ${ }^{1,2,3}$, Christine Dos Santos ${ }^{4}$, Consuelo Espinosa ${ }^{2}$, Sylvie Salenave ${ }^{2}$, Françoise Galland ${ }^{2}$, \\ Yves Le Bouc $^{5,6,7}$, Patrick Maison ${ }^{8,9,10}$, Pierre Bougnères ${ }^{4,11,12}$ and Philippe Chanson ${ }^{1,2,3}$ \\ ${ }^{1}$ Université Paris-Sud 11, Faculté de Médecine Paris-Sud, UMR-S693, Le Kremlin Bicêtre F-94276, France, ${ }^{2}$ Assistance Publique-Hôpitaux de Paris, \\ Hôpital de Bicêtre, Service d'Endocrinologie et des Maladies de la Reproduction, 78 rue du Général Leclerc, Le Kremlin Bicêtre F-94275, France, ${ }^{3}$ INSERM, \\ U693, Le Kremlin Bicêtre F-94276, France, ${ }^{4}$ INSERM, U561, Paris F-75014, France, ${ }^{5}$ Université Pierre et Marie Curie-Paris 6, Paris F-75012, \\ France, ${ }^{6}$ Assistance Publique-Hôpitaux de Paris, Hôpital Armand-Trousseau, Explorations Fonctionnelles Endocriniennes, Paris F-75012, France, \\ ${ }^{7}$ INSERM, U515, Paris F-75012, France, ${ }^{8}$ Assistance Publique-Hôpitaux de Paris, Hôpital Henri Mondor, Service de Pharmacologie Clinique et Unité de \\ Recherche Clinique, Créteil F-94010, France, ${ }^{9}$ Université Paris 12, Créteil F-94010, France, ${ }^{10}$ INSERM, U421, Créteil F-94010, France, ${ }^{11}$ Assistance \\ Publique-Hôpitaux de Paris, Groupe Hospitalier Cochin Saint Vincent de Paul, Service d'Endocrinologie Pédiatrique, Paris F-75014, France and \\ ${ }^{12}$ Université René Descartes Paris 5, Paris F-75014, France
}

(Correspondence should be addressed to P Chanson at Service d'Endocrinologie et Maladies de la Reproduction, Hôpital de Bicêtre; Email: philippe.chanson@bct.aphp.fr)

\begin{abstract}
Context: A discrepancy between serum GH and IGF1 concentrations is frequent in patients with acromegaly. Here, we examined whether the exon 3-deleted (d3) GH receptor (GHR) variant, which has been linked to increased responsiveness to GH treatment in short children, influences the GH/IGF1 relationship in patients with acromegaly.

Objective: To study the possible influence of the GHR genotype on the GH/IGF1 relationship in untreated acromegalic patients.

Design: GHR genotype analysis with retrospective clinical and biochemical data collection performed in a single third-reference medical center.

Patients and methods: Clinical data were obtained from the medical records of 105 acromegalic patients who had GH and IGF1 assays in the same laboratory and who were genotyped for the full-length (fl) or d3-GHR alleles.

Results: The distribution of GHR genotypes was $51 \% \mathrm{fl} / \mathrm{fl}, 30 \% \mathrm{fl} / \mathrm{d} 3$, and $19 \% \mathrm{~d} 3 / \mathrm{d} 3$. Patients with $\mathrm{d} 3 / \mathrm{d} 3$ genotype were younger than the patients in the other two groups $(P<0.05)$. Baseline GH and IGF1 concentrations did not differ among the three groups. The linear correlation between GH and IGF1 concentrations was similar in the three genotypic groups.

Conclusions: The exon 3 GHR genotype does not affect the GH/IGF1 relationship in untreated acromegalic patients with high circulating GH and IGF1 levels.

European Journal of Endocrinology 161 231-235
\end{abstract}

\section{Introduction}

Randomly measured serum GH and insulin-like growth factor-1 (IGF1) concentrations are currently used as indices of acromegaly disease activity (1). The relationship between $\log _{10}$ serum GH and serum IGF1 concentrations is linear in patients with active disease $(2,3)$, but discordant serum GH and IGF1 levels are observed in many acromegalic patients $(2,4-6)$. Although the serum IGF1 level is mainly dependent on the GH level in acromegaly, IGF1 responsiveness to GH may be modulated by other factors, including gender, age, nutrition, body composition, and previous therapy $(2,7,8)$. Genetic factors may also influence individual GH sensitivity. The GH receptor gene $(G H R)$ is an obvious candidate. Among other polymorphisms, GHR bears a common microdeletion leading to exon 3 retention (full-length GHR, fl) or exclusion (exon 3-deleted GHR, d3) (9). Approximately half of Europeans carry at least one d3 allele (10). We have previously observed a link between the d3-GHR variant and increased responsiveness to GH therapy in short children, and demonstrated increased GH signal transduction by the transfected d3-GHR isoform (11). Subsequent studies extended this observation to children with Turner's syndrome (12), children with GH deficiency (GHD) (13, 14), and adults with GHD (15). However, for reasons that are controversial (16), other teams failed to confirm these findings in $\operatorname{GHD}(17,18)$ or short for gestational age children $(19,20)$. The influence of the GHR genotype on human postnatal growth velocity and final adult height is also a matter of debate $(21,22)$. Finally, two recent studies have analyzed the impact of d3-GHR polymorphism in 
acromegalic patients leading, once again, to divergent conclusions $(10,23)$. Here, we analyzed the influence of the exon 3 GHR genotype on the GH/IGF1 relationship in a cohort of 105 untreated acromegalic patients.

\section{Patients and methods}

\section{Study population}

We reviewed data on 105 acromegalic patients $(57$ women and 48 men). Acromegaly was diagnosed between January 1993 and February 2007, based on the usual criteria (1). Clinical parameters (age, gender, height, weight, pituitary tumor size, anterior pituitary insufficiency and hormone replacement therapy, glucose intolerance or diabetes mellitus, and arterial hypertension at diagnosis) and biological data (mean serum GH and IGF1 concentrations prior to acromegaly treatment) were collected from the medical records. Median age at diagnosis was 43 years (range 20-75 years). Eighty-three patients $(79 \%)$ presented with a pituitary macroadenoma and $22(21 \%)$ patients with a pituitary microadenoma. Forty-four patients $(42 \%)$ had anterior pituitary hormone deficits, nine of them had panhypopituitarism. Four patients were receiving oral estrogen, two transdermal estrogen, and one androgen replacement therapy. Impaired glucose tolerance or diabetes mellitus was present in $39(37 \%)$ patients and arterial hypertension in $35(33 \%)$ patients. A blood sample was taken from each patient for GHR genotyping between January 2003 and February 2007.

\section{Hormone measurements}

Serum GH was measured with highly sensitive solidphase two-site sandwich assays. As several assays were used, we converted GH concentrations from $\mathrm{ng} / \mathrm{ml}$ to $\mathrm{mIU} / \mathrm{l}$ by using the appropriate conversion factors for each method and standard. Reported basal GH serum concentrations are the mean values for at least four serum samples obtained during an hourly profile. Serum IGF1 concentrations were measured as described by Mercado et al. (24). Briefly, until 1998, sera were gel filtered on Ultrogel AcA 54 columns in acetic acid. RIA was used for IGF1, with a specific polyclonal antihuman IGF1 antibody. Recombinant human IGF1 was used as both standard and tracer. Unknown samples were studied at three concentrations, each in duplicate, plus one blank (tube without antibody). Intra- and inter-assay coefficient of variations were 4.8 and $10 \%$ respectively. After 1998, the same IGF1 RIA was used after separating IGF from binding proteins, in a new method. Plasma was incubated for $30 \mathrm{~min}$ at room temperature in acidic medium $(0.01 \mathrm{M} \mathrm{HCl})$ and then ultrafiltered on a Centricon 30. After lyophilization, the IGF-containing ultrafiltrate was taken up in $0.1 \mathrm{M}$ phosphate buffer $(0.1 \%$ BSA, pH 7.4$)$ and analyzed by
RIA. Importantly, the reference IGF1 concentrations with this method were the same as with the previous method. Thus, throughout this retrospective study, reference IGF1 concentrations in our laboratory remained unchanged: normal-for-age serum levels of IGF1 (mean \pm s.D. in $\mu \mathrm{g} / \mathrm{l}$ ) were as follows: 16-20 y, $405 \pm 70 ; 20-30$ y, $310 \pm 55 ; 30-40$ y, 275 450 ;

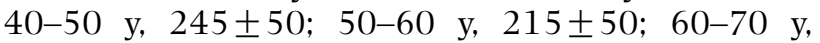
$185 \pm 50 ; 70-80$ y, $165 \pm 50$; and $>80$ y, $155 \pm 50$. Age-adjusted IGF1 values were calculated with agespecific reference ranges for our IGF1 assay (IGF1\% $=$ patient's IGF1/age-specific upper limit $\times 100$; the age-specific upper limit=mean IGF1 normal for age and sex +2 s.D.). We did not use individual IGF1 SDS for two reasons: first, it is well known that the distribution is not Gaussian in healthy adults, necessitating correction to obtain the SDS; and second, many IGF1 values exceeded five, at which SDS is considered irrelevant at the individual level.

\section{Genotyping}

Genomic DNA was extracted from peripheral blood leukocytes. The GHR exon 3 genotype (fl/fl, $\mathrm{d} 3 / \mathrm{fl}$, and d3/d3) was determined by simple multiplex PCR as described by dos Santos et al. (11) and confirmed by allele-specific PCR (25).

\section{Ethics}

Written informed consent for genetic analysis was obtained from each patient. The study was approved by the local ethics committee and was performed in keeping with French legislation.

\section{Statistical analysis}

Data are reported as means \pm s.E.M. For correlation analyses, serum GH concentrations were expressed as $\log _{10}$ values. Data were analyzed with Prism version 4 and statistical analysis software (SAS). The level of significance was set at $P=0.05$ Groups were compared. with $\chi^{2}$-test, Fischer's exact test, Kruskal-Wallis test followed by Dunn's multiple comparison test, Wilcoxon rank test, and Spearman rank correlation analysis. To evaluate the influence of the GHR genotype on the baseline serum IGF1 concentration, we fitted a multiple linear regression model with age, gender, body mass index (BMI), and serum GH concentrations as potentially predictive variables.

\section{Results}

The GHR genotypes were $\mathrm{fl} / \mathrm{fl}$ in 54 cases $(51 \%), \mathrm{d} 3 / \mathrm{fl}$ in 31 cases $(30 \%)$, and $\mathrm{d} 3 / \mathrm{d} 3$ in 20 cases $(19 \%)$. Baseline clinical and biochemical characteristics of the three genotypic groups are shown in Table 1 . There was no 
Table 1 Baseline clinical and biological characteristics of the acromegalic patients, according to the GH receptor (GHR) genotype.

\begin{tabular}{lllll}
\hline Genotype & fl/fl & $\mathbf{f l / d 3}$ & $\mathbf{d 3 / d 3}$ & $\mathbf{P}$ \\
\hline$n$ & 54 & 31 & 20 & \\
Age (years) & $46 \pm 2$ & $44.5 \pm 2.4$ & $35.7 \pm 2.3$ & \\
Sex (F/M) & $33 / 21$ & $13 / 18$ & $11 / 9$ & $\mathrm{NS}$ \\
Height (cm) & $171.0 \pm 1.4$ & $172.7 \pm 1.5$ & $173.7 \pm 2.5$ & $\mathrm{NS}$ \\
BMl & $26.5 \pm 0.6$ & $27.5 \pm 0.6$ & $26.2 \pm 0.8$ & $\mathrm{NS}$ \\
Macroadenoma (\%) & 81 & 77 & 75 & $\mathrm{NS}$ \\
Pituitary deficiency (\%) & 43 & 52 & 25 & $\mathrm{NS}$ \\
Diabetes/lGT (\%) & 37 & 39 & 35 & $\mathrm{NS}$ \\
Hypertension (\%) & 33 & 39 & 25 & $\mathrm{NS}$ \\
GH (mIU/l) & $63.7 \pm 10.1$ & $74.7 \pm 20.3$ & $93.8 \pm 26.4$ & $\mathrm{NS}$ \\
IGF1 (ng/ml) & $992.4 \pm 52.4$ & $957.0 \pm 75.6$ & $1029.0 \pm 95.7$ & $\mathrm{NS}$ \\
IGF1 (\%) & $289.2 \pm 16.1$ & $289.2 \pm 28.4$ & $284.3 \pm 25.4$ & $\mathrm{NS}$ \\
\hline
\end{tabular}

Values are means \pm S.E.M.; IGF1 (\%) is the percentage of the upper limit (mean IGF1+2 s.D.) of the age-specific references range of IGF1. IGT, impaired glucose tolerance.

difference in gender, height, BMI, percentage of macroadenomas, frequency of impaired glucose tolerance/diabetes mellitus, frequency of arterial hypertension, or the pre-treatment GH and IGF1 concentrations across the three groups, but $\mathrm{d} 3 / \mathrm{d} 3$ patients were younger than the patients in the other two groups. As expected, a linear correlation between serum GH and IGF1 concentrations was observed in the three groups (Fig. 1) according to closely similar equations. Similar linear associations were found when IGF1 values were adjusted for age. The multiple regression model showed that IGF1 concentrations were correlated with $\log _{10}$ serum GH $(P<0.0001)$, seemed to be associated with gender without reaching statistical significance $(P=0.07)$, and did not correlate with age, BMI, or the GHR genotype.

\section{Discussion}

As GH and IGF1 concentrations are used as indices of disease activity in acromegaly (1), factors potentially influencing the GH/IGF1 axis are of major clinical importance. Here, we analyzed whether the d3-GHR variant, which has been linked to increased responsiveness to $\mathrm{GH}$ treatment in short children, influences the GH/IGF1 relationship in patients with untreated acromegaly.

Two recent studies have previously examined the impact of GHR variants on serum GH and IGF1 concentrations in acromegalic patients. Schmid et al. reported, in a cohort of 44 untreated acromegalic patients, lower $\mathrm{GH}$ concentrations in $\mathrm{d} 3-\mathrm{GHR}$ carriers than in fl/fl patients, whereas the IGF1 concentrations did not differ among the GHR genotype groups. The authors suggested that patients carrying d3-GHR allele require lower $\mathrm{GH}$ concentrations to produce a given increase in serum IGF1 and to develop acromegalic symptoms (10). By contrast, Mercado et al. found no difference in GH or IGF1 concentrations in 152 acromegalic patients at diagnosis, but d3-GHR-carrying patients presented with higher IGF1 concentrations after acromegaly treatment. Interestingly, the exon 3 deletion was a stronger predictor of persistently elevated IGF1 concentrations during post-treatment follow-up than age at diagnosis, gender, and even baseline GH and IGF1 levels or tumor size. Surprisingly, the expected correlation between IGF1 and $\log _{10}$ GH concentrations was only weak in d3-GHR patients and was not confirmed in fl-GHR patients (23).

In our study, which involved 105 untreated acromegalic patients, the distribution of the GHR genotypes was comparable with previous study populations (10, $11,23)$. Of note, $\mathrm{d} 3 / \mathrm{d} 3$ carriers were significantly younger at diagnosis than $\mathrm{fl} / \mathrm{fl}$ and $\mathrm{fl} / \mathrm{d} 3$ patients, suggesting that $\mathrm{d} 3-\mathrm{GHR}$ could promote the occurrence of acromegalic phenotype at a younger age. Nevertheless, such difference was not found in previous studies $(10,23)$. At variance with the findings of

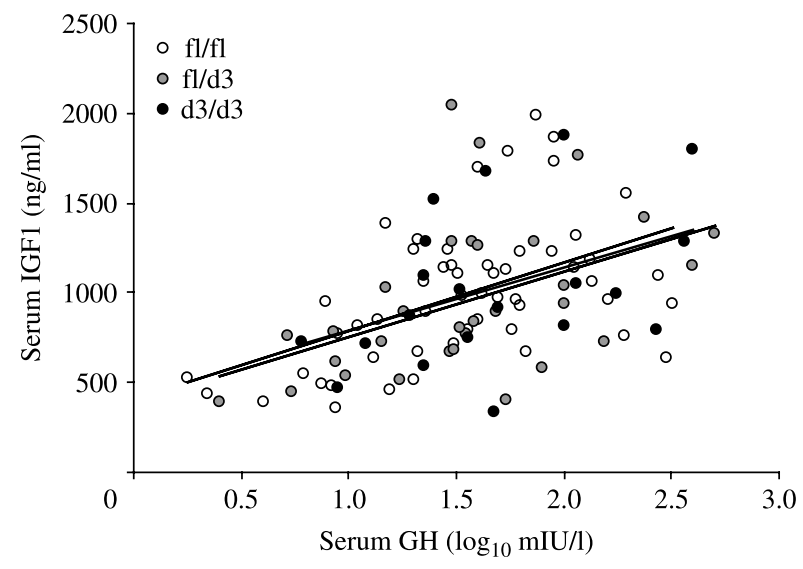

Figure 1 Association between baseline IGF1 concentrations and $\log _{10} \mathrm{GH}$ concentrations in acromegalic patients with full-length $G H R(\mathrm{fl} / \mathrm{fl})$ and exon 3-deleted GHR variants (d3/fl and $\mathrm{d} 3 / \mathrm{d} 3)$ at diagnosis. No influence of the GHR genotype was found (fl/fl: IGF1 = $377 \log _{10} \mathrm{GH}+411, R=0.50, P<0.0001 ; \mathrm{d} 3 / \mathrm{fl}:$ IGF1 = 365 $\log _{10} \mathrm{GH}+391, R=0.53, P<0.001 ; \mathrm{d} 3 / \mathrm{d} 3: \mathrm{IGF} 1=346 \log _{10}$ $\mathrm{GH}+448, R=0.46, P<0.05)$. 
Schmid et al. (10) and in accordance with the recent study of Mercado et al. (23), we observed no difference in baseline GH and IGF1 concentrations across the GHR genotypic groups at the time of acromegaly diagnosis. This negative finding is corroborated in our study by clear linear association between serum IGF1 and $\log _{10}$ $\mathrm{GH}$ according to closely similar equations among the GHR genotypes.

In vitro, GH signal transduction by transfected d3-GHR isoforms is increased when using both physiological and supraphysiological GH concentrations, similar to those observed in active acromegalic patients (11). Nevertheless, chronic exposition to such grossly excessive $\mathrm{GH}$ concentrations in vivo may mask the enhanced GH sensitivity of d3-GHR. Considering the data of Mercado et al. d3-GHR genotype may possibly influence the GH/IGF1 relationship only when patients have recovered more normal circulating GH concentrations after acromegaly treatment. When GH concentrations are very high, owing to unrestricted chronic tumoral secretion, the influence of the GHR variant (if any) is undetectable, as expected from a system where GH signaling is maximal. Indeed, GH concentrations in active acromegaly are well beyond the dose-response curve that can be observed, for example, in short children treated with supraphysiological doses of $\mathrm{GH}$ (11). Anyway, this hypothesis requires to be tested in a prospective manner during acromegaly follow-up, since different therapeutic modalities and their variable duration (very difficult to address in a retrospective evaluation) may also impact the post-treatment GH/IGF1 relationship.

In keeping with the known effect of gender on the GH/IGF1 axis in untreated acromegaly (2), we observed a tendency of association between sex and IGF1 concentrations. Oral estrogen treatment, which is known to influence the GH/IGF1 pathway (26), was only used in four patients and did not interfere with the results. In acromegaly, the GH and IGF1 excess leads to a preferential reduction in visceral and s.c. fat, whereas intramuscular fat (27) and fat-free mass (28) increase. The relationship between GH/IGF1 status and body composition is therefore complex. In our study, BMI was not related to IGF1 levels. Finally, at variance with the study of Mercado et al. the prevalence of the diabetes mellitus was not associated with GHR genotypes.

In conclusion, the GHR genotype does not affect the GH/IGF1 relationship in patients with untreated acromegaly. Given the critical role of circulating $\mathrm{GH}$ and IGF1 levels in acromegaly patient management $(1,29)$, further investigations are needed to determine the contribution of other genetic factors to GH/IGF1 pathway modulation.

\section{Declaration of interest}

The Service d'Endocrinologie et des Maladies de la Reproduction, Hôpital de Bicêtre, and Université Paris-Sud 11, receives unrestricted educational and research grants from Novartis, Ipsen, and Pfizer. P Kamenicky, C Dos Santos, C Espinosa, S Salenave, F Galland, Y Le Bouc, P Maison, and P Bougnères have nothing to declare. P Chanson has received consulting and lecture fees from Novartis, Ipsen, and Pfizer.

\section{Funding}

This work did not receive any specific financial support.

\section{Acknowledgements}

We thank the nursing staff of Service d'Endocrinologie et des Maladies de la Reproduction (Hôpital de Bicêtre, Le Kremlin-Bicêtre, France) for their contribution to this work. Genotyping was carried out with the precious technical help of Myriam Oufadem (INSERM U561, Paris, France). We also thank Alexia Letierce (Unité de Recherche Clinique, Hôpital de Bicêtre) for her help in statistical analyses and Dr Oumayma Khallouf (Service de Génétique Moléculaire, Pharmacogénétique et Hormonologie, Hopital de Bicêtre) for GH measurements. P Kamenicky was the recipient of a fellowship from the Ministère de l'Enseignement Supérieur et de la Recherche, France.

\section{References}

1 Melmed S. Medical progress: acromegaly. New England Journal of Medicine $20063552558-2573$.

2 Parkinson C, Ryder WD \& Trainer PJ. The relationship between serum GH and serum IGF-I in acromegaly is gender-specific. Journal of Clinical Endocrinology and Metabolism $2001 \mathbf{8 6}$ 5240-5244.

3 Dobrashian RD, O'Halloran DJ, Hunt A, Beardwell CG \& Shalet SM. Relationships between insulin-like growth factor-1 levels and growth hormone concentrations during diurnal profiles and following oral glucose in acromegaly. Clinical Endocrinology 1993 38 589-593.

4 Dimaraki EV, Jaffe CA, DeMott-Friberg R, Chandler WF \& Barkan AL. Acromegaly with apparently normal GH secretion: implications for diagnosis and follow-up. Journal of Clinical Endocrinology and Metabolism 200287 3537-3542.

5 Freda PU, Nuruzzaman AT, Reyes CM, Sundeen RE \& Post KD. Significance of 'abnormal' nadir growth hormone levels after oral glucose in postoperative patients with acromegaly in remission with normal insulin-like growth factor-I levels. Journal of Clinical Endocrinology and Metabolism 200489 495-500.

6 Alexopoulou O, Bex M, Abs R, T'Sjoen G, Velkeniers B \& Maiter D. Divergence between growth hormone and insulin-like growth factor-I concentrations in the follow-up of acromegaly. Journal of Clinical Endocrinology and Metabolism 200893 1324-1330.

7 Ho KY, Evans WS, Blizzard RM, Veldhuis JD, Merriam GR, Samojlik E, Furlanetto R, Rogol AD, Kaiser DL \& Thorner MO. Effects of sex and age on the 24-hour profile of growth hormone secretion in man: importance of endogenous estradiol concentrations. Journal of Clinical Endocrinology and Metabolism 198764 $51-58$.

8 Barkan AL, Halasz I, Dornfeld KJ, Jaffe CA, Friberg RD, Chandler WF \& Sandler HM. Pituitary irradiation is ineffective in normalizing plasma insulin-like growth factor I in patients with acromegaly. Journal of Clinical Endocrinology and Metabolism 1997 82 3187-3191.

9 Pantel J, Machinis K, Sobrier ML, Duquesnoy P, Goossens M \& Amselem S. Species-specific alternative splice mimicry at the growth hormone receptor locus revealed by the lineage of retroelements during primate evolution. Journal of Biological Chemistry 2000275 18664-18669. 
10 Schmid C, Krayenbuehl PA, Bernays RL, Zwimpfer C, Maly FE \& Wiesli P. Growth hormone (GH) receptor isoform in acromegaly: lower concentrations of GH but not insulin-like growth factor-1 in patients with a genomic deletion of exon 3 in the $\mathrm{GH}$ receptor gene. Clinical Chemistry 200753 1484-1488.

11 Dos Santos C, Essioux L, Teinturier C, Tauber M, Goffin V \& Bougneres P. A common polymorphism of the growth hormone receptor is associated with increased responsiveness to growth hormone. Nature Genetics 200436 720-724.

12 Binder G, Baur F, Schweizer R \& Ranke MB. The d3-growth hormone $(\mathrm{GH})$ receptor polymorphism is associated with increased responsiveness to $\mathrm{GH}$ in Turner syndrome and short small-forgestational-age children. Journal of Clinical Endocrinology and Metabolism 200691 659-664.

13 Jorge AA, Marchisotti FG, Montenegro LR, Carvalho LR, Mendonca BB \& Arnhold IJ. Growth hormone (GH) pharmacogenetics: influence of $\mathrm{GH}$ receptor exon 3 retention or deletion on first-year growth response and final height in patients with severe GH deficiency. Journal of Clinical Endocrinology and Metabolism 200691 1076-1080.

14 Raz B, Janner M, Petkovic V, Lochmatter D, Eble A, Dattani MT, Hindmarsh PC, Fluck CE \& Mullis PE. Influence of growth hormone $(\mathrm{GH})$ receptor deletion of exon 3 and full-length isoforms on $\mathrm{GH}$ response and final height in patients with severe $\mathrm{GH}$ deficiency. Journal of Clinical Endocrinology and Metabolism 2008 $93974-980$.

15 van der Klaauw AA, van der Straaten T, Baak-Pablo R, Biermasz NR, Guchelaar HJ, Pereira AM, Smit JW \& Romijn JA. Influence of the d3-growth hormone receptor isoform on shortterm and long-term treatment response to growth hormone replacement in growth hormone deficient adults. Journal of Clinical Endocrinology and Metabolism $2008932828-2834$.

16 Bougneres P \& Goffin V. The growth hormone receptor in growth. Endocrinology and Metabolism Clinics of North America 200736 1-16.

17 Blum WF, Crowe BJ, Quigley CA, Jung H, Cao D, Ross JL, Braun L \& Rappold G. Growth hormone is effective in treatment of short stature associated with short stature homeobox-containing gene deficiency: two-year results of a randomized, controlled, multicenter trial. Journal of Clinical Endocrinology and Metabolism 2007 92 219-228.

18 Pilotta A, Mella P, Filisetti M, Felappi B, Prandi E, Parrinello G, Notarangelo LD \& Buzi F. Common polymorphisms of the growth hormone $(\mathrm{GH})$ receptor do not correlate with the growth response to exogenous recombinant human $\mathrm{GH}$ in $\mathrm{GH}$-deficient children. Journal of Clinical Endocrinology and Metabolism $2006 \mathbf{9 1}$ 1178-1180.

19 Carrascosa A, Esteban C, Espadero R, Fernandez-Cancio M, Andaluz P, Clemente M, Audi L, Wollmann H, Fryklund L \& Parodi L. The d3/fl-growth hormone $(\mathrm{GH})$ receptor polymorphism does not influence the effect of $\mathrm{GH}$ treatment $(66 \mathrm{microg} / \mathrm{kg}$ per day) or the spontaneous growth in short non-GH-deficient smallfor-gestational-age children: results from a two-year controlled prospective study in 170 Spanish patients. Journal of Clinical Endocrinology and Metabolism $2006913281-3286$.
20 Carrascosa A, Audi L, Esteban C, Fernandez-Cancio M, Andaluz P, Gussinye M, Clemente M, Yeste D \& Albisu MA. Growth hormone $(\mathrm{GH})$ dose, but not exon 3-deleted/full-length $\mathrm{GH}$ receptor polymorphism genotypes, influences growth response to twoyear GH therapy in short small-for-gestational-age children. Journal of Clinical Endocrinology and Metabolism $2008 \mathbf{9 3}$ 147-153.

21 Jensen RB, Vielwerth S, Larsen T, Greisen G, Leffers H \& Juul A. The presence of the $\mathrm{d} 3$-growth hormone receptor polymorphism is negatively associated with fetal growth but positively associated with postnatal growth in healthy subjects. Journal of Clinical Endocrinology and Metabolism 200792 2758-2763.

22 Kenth G, Shao Z, Cole DE \& Goodyer CG. Relationship of the human growth hormone receptor exon 3 genotype with final adult height and bone mineral density. Journal of Clinical Endocrinology and Metabolism 200792 725-728.

23 Mercado M, Gonzalez B, Sandoval C, Esquenazi Y, Mier F, Vargas G, de los Monteros AL \& Sosa E. Clinical and biochemical impact of the $\mathrm{d} 3$ growth hormone receptor genotype in acromegaly. Journal of Clinical Endocrinology and Metabolism $2008 \mathbf{9 3}$ 3411-3415.

24 Galland F, Kamenicky P, Affres H, Reznik Y, Pontvert D, Le Bouc Y, Young J \& Chanson P. McCune-Albright syndrome and acromegaly: effects of hypothalamopituitary radiotherapy and/or pegvisomant in somatostatin analog-resistant patients. Journal of Clinical Endocrinology and Metabolism 200691 4957-4961.

25 Audi L, Esteban C, Carrascosa A, Espadero R, Perez-Arroyo A, Arjona R, Clemente M, Wollmann H, Fryklund L \& Parodi LA. Exon 3-deleted/full-length growth hormone receptor polymorphism genotype frequencies in Spanish short small-for-gestational-age (SGA) children and adolescents $(n=247)$ and in an adult control population $(n=289)$ show increased fl/fl in short SGA. Journal of Clinical Endocrinology and Metabolism 200691 5038-5043.

26 Leung KC, Johannsson G, Leong GM \& Ho KK. Estrogen regulation of growth hormone action. Endocrine Reviews 2004 25 693-721.

27 Freda PU, Shen W, Heymsfield SB, Reyes-Vidal CM, Geer EB, Bruce JN \& Gallagher D. Lower visceral and subcutaneous but higher intermuscular adipose tissue depots in patients with $\mathrm{GH}$, IGF-I excess due to acromegaly. Journal of Clinical Endocrinology and Metabolism $2008932334-2343$.

28 O'Sullivan AJ, Kelly JJ, Hoffman DM, Freund J \& Ho KK. Body composition and energy expenditure in acromegaly. Journal of Clinical Endocrinology and Metabolism 199478 381-386.

29 Marzullo P, Di Somma C, Pratt KL, Khosravi J, Diamandis A, Lombardi G, Colao A \& Rosenfeld RG. Usefulness of different biochemical markers of the insulin-like growth factor (IGF) family in diagnosing growth hormone excess and deficiency in adults. Endocrinology and Metabolism 200186 3001-3008.

Received 5 April 2009

Accepted 5 May 2009 